\title{
INTERPRETASI HADIS-HADIS TENTANG NIKAH MUT'AH (KAJIAN TEMATIK)
}

\author{
Sinta Rahmatil Fadhilah \\ UIN Sulthan Thaha Saifuddin Jambi \\ Email: sintarahmatilfadhilah@uinjambi.ac.id \\ Umu Nisa Ristiana \\ UIN Sunan Kalijaga Yogyakarta \\ Email: umunisaristiana26@gmail.com
}

\section{Siti Aminah}

UIN Sulthan Thaha Saifuddin Jambi

Email: sitiaminah@uinjambi.ac.id

\begin{abstract}
The understanding of a hadith that tends to be textual, without considering all the aspects that surround it, sometimes creates misinterpretations. One example of what became viral at the end of 2017 was nikah mut'ah, which was made viral by the online site nikahsirri.com. The issue of nikah mut'ah then became the spotlight of various parties. Nikah mut'ah is a marriage that is limited by time. In understanding the hadith about nikah mut'ah, the scholars have different opinions, some say that nikah mut'ah is haram and some say that marriage is permissible. So in order to understand the hadith, a methodology is needed. This article is a literature research-based research using the thematic methodology in understanding the related traditions about nikah mut'ah. So, in conclusion, the mut'ah marriage that was allowed by the Prophet was during the period before the stability of Islamic law, that is, it was allowed at the beginning of Islam when traveling and in war. He made concessions for his friends who were fighting in Allah's way to get married within a certain time limit, for fear that they would fall into adultery. However, then mut'ah marriage was forbidden.
\end{abstract}

Keywords: Hadith, Interpretation, Mut'ah, Thematic

\begin{abstract}
Abstrak
Pemahaman tentang sebuah hadis yang cenderung tekstual, tanpa mempertimbangkan segala aspek yang melingkupinya, terkadang
\end{abstract}


membuat salah pengartian. Salah satu contoh yang menjadi pembicaraan yang sedang viral di akhir tahun 2017 adalah nikah mut'ah, yang divirakan oleh situs online nikahsirri.com. Permasalahan tentang nikah mut'ah kemudian menjadi sorotan dari berbagai pihak. Nikah mut'ah adalah nikah yang dibatasi oleh waktu. Dalam memahami hadis tentang nikah mut'ah para ulama berbeda pendapat, ada yang mengatakan nikah mut'ah tersebut haram dan ada yang mengatakan bahwa nikah itu dibolehkan. Jadi untuk memahami hadis diperlukan sebuah metodologi, artikel ini merupakan penelitian berbasis penelitian pustaka dengan menggunakan metodologi tematik dalam memahami hadis-hadis terkait tentang nikah mut'ah. Jadi, kesimpulannya nikah mut'ah yang diperbolehkan oleh Rasulullah adalah ketika masa sebelum stabilnya syariat Islam, yaitu diperkenankannya pada awal Islam ketika dalam keadaan bepergian dan peperangan. Beliau memberi kelonggaran kepada sahabat-sahabatnya yang ikut berperang di jalan Allah untuk nikah dengan batas waktu tertentu, karena dikhawatirkan mereka akan jatuh ke dalam perzinahan. Akan tetapi kemudian nikah mut'ah itu diharamkan.

Kata Kunci: Hadis, Interpretasi, Nikah Mut'ah, Tematik

\section{Pendahuluan}

Suatu masa yang indah dalam siklus kehidupan adalah ketika bertemunya dua insan dalam akad yang halal, bersanding di pelaminan yang diimpikan, menggapai hal yang sama-sama diinginkan, menuju suatu pernikahan yang utuh dan bahagia. Karena sejatinya ketika dua insan yang bersatu tidak lain dan tidak bukan hal yang diinginkan adalah kebahagiaan, yakni hidup yang sakinah, mawaddah dan rahmah. Kebahagiaan tersebut tidak hanya di dunia akan tetapi juga kebahagiaan di akhirat. Pernikahan ibarat melayarkan kapal menuju lautan lepas, memerlukan pengatahuan dan keterampilan untuk mengendalikkannya agar tidak diterpa badai dan walaupun badai itu datang menerpa nahkoda ataupun awak kapal tahu cara mengatasinya. Begitupun sebaliknya berlayar tanpa pengetahuan dan keterampilan hidup, maka kapal tersebut akan hanyut, terombang-ambing, bahkan musnah ditelan lautan.

Pernikahan berarti menyatukan dua pribadi, dua pikiran, dua latar belakang yang berbeda, dua jiwa menjadi satu kesatuan yang 
diikat oleh komitmen yakni menikah untuk hidup bersama sepanjang masa hingga ke syurga-Nya. Sebagaimana dijelaskan dalam QS. Al-Rum [30]: 21 yang artinya: "Dan di antara tanda-tanda kekuasaan-Nya ialah Dia menciptakan untukmu istri-istri dari jenismu sendiri, supaya kamu cenderung dan merasa tenteram kepadanya, dan dijadikan-Nya di antaramu rasa kasib dan sayang. Sesunggubnya pada yang demikian itu benar-benar terdapat tanda-tanda bagi kaum yang berfikir."

Huruf lam pada kata litaskunu sebagai lam ta'lil (alasan atau tujuan), yakni tujuan pernikahan adalah ketenangan dan kelanggenan. $^{2}$ Jadi, ayat di atas menjelaskan, bahwa Allah menciptakan banyak tanda-tanda di muka bumi, tanda-tanda itu berupa penciptaan bumi dan langit, tumbuh-tumbuhan, hewan dan manusia. Pada ayat ini Allah menjelaskan salah satu tanda kebesaran-Nya yaitu menciptakan manusia berpasang-pasangan. Dengan tujuan untuk menciptakan rasa tentram dan kecenderungan kepada pasangannya, dan Allah menanamkan rasa kasih dan sayang.

Maha besar Allah yang telah menciptakan makhluk-Nya berpasang-pasangan, saling berbagi kasih sayang dan mempunyai keturunan. Karena pernikahan adalah satu-satunya cara menjaga kontinuitas kehidupan dan pemakmuran dunia. Kalau bukan karenanya, spesies manusia akan punah. Pernikahan juga merupakan motivator utama bagi manusia untuk bekerja dan berproduksi. Kalau bukan karenanya, orang tidak akan bersemangat untuk bekerja dan mencari rezeki. ${ }^{3}$ Maka sangat umum sekali dilihat perubahan kehidupan seseorang ketika sudah menikah, baik itu kehidupan secara psikologi, fisik, maupun secara

${ }^{1}$ Departemen Agama RI, Al-Qur'an Al-Karim dan Terjemahannya (Jakarta: Maghfiroh Pustaka, 2006), 406.

2 Ali Yusuf As-Subki, Fiqh Keluarga: Pedoman Bekeluarga dalam Islam (Jakarta: Amzah, 2010), 28.

3 Syaikh Fuad Shalih, Untukmu yang Akan Menikah dan Telah Menikah (Jakarta: Pustaka al-Kautsar, 2006), 6. 
finansial. Para pasangan akan berlomba-lomba memperbaiki kualitas diri dan kehidupan demi kemajuan.

Jika pernikahan adalah bertemunya dua insan, maka tidak dipungkiri pula aka ada perpisahan, yakni sebuah perceraian. Walaupun perceraian ini tidak diharamkan oleh Allah Swt., namun Allah tidak menyukai hal tersebut. Baik itu perpisahan yang disengajakan atau tidak. Seperti contoh ketika orang menikah kemudian muncul permasalahan yang datang, namun tidak ada kesanggupan lagi untuk menyelesaikan permasalahan tersebut, maka perpisahan adalah satu-satunya jalan yang mau tidak mau harus ditempuh. Namun, bagaimana dengan pernikahan mut'ah yang dengan sengaja harus berpisah jika masanya telah tiba, tanpa ada permasalahan sama sekali. Walaupun ada kesepakatan di awal ketika ingin melangsungkan pernikahan, bahwa pernikahan yang akan dilakukan nanti akan berakhir pada waktu yang telah ditentukan. Lalu bagaimana dengan pihak yang terkait dalam pernikahan tersebut.

Pernikahan mut'ah sudah terjadi pada masa Rasulullah saw., namun pada zaman sekarang yang sudah serba canggih akan teknologi dan ilmu pengetahuan, yang mana jarak tidak lagi menjadi penghalang dan waktu tidak lagi menjadi permasalahan. Ternyata masih juga terjadi nikah mut'ah atau nikah kontrak dikalangan masyarakat Muslim. Salah satu yang membolehkan nikah mut'ah adalah golongan Syiah. Syiah selalu menganggap nikah mut'ah sebagai suatu yang khusus dan berusaha untuk mempertahankannya sebagai sebuah intuisi dalam masyarakat Islam. Hukum Syiah seringkali disebut sebagai mazhab hukum Ja'fari, karena dalam realitas imam keenam Ja'far al-Sadiq adalah pendirinya. Imam Ja'far menganggap nikah mut'ah sebagai rahmat ilahi yang menyelamatkan manusia dari zina dan hukuman Tuhan. ${ }^{4}$

${ }^{4}$ Sachiko Murata, Lebih Jelas Tentang Nikah Mut'ah Pendekatan Sunni dan Syiah (Jakarta: PT. Raja Grafindo, 2001), 130. 
Kasus yang sempat heboh terkait nikah mut'ah pun viral di dunia maya bahkan berdampak kepada dunia nyata. Banyak media massa memberitakan terkait pernikahan mut'ah di salah satu situs online yaitu nikahsirrih.com. Di antaranya, berita yang berjudul "Situs Lelang Perawan-Kawin Kontrak, Mentri Yobana Mengecam" yang dimuat oleh DetikNews. Dalam berita ini Yohana menegaskan bahwa kawin kontrak adalah salah satu bentuk eksploitasi kaum perempuan, hal ini tentunya melanggar undang-undang tentang pemberantasan tindak pidana perdagangan orang. Program kawin kontrak tersebut sama halnya dengan pelacuran terselubung yang dibalut dengan modus agama.

Pada dasarnya, persoalan nikah mut'ah memang dibicarakan dalam teks-teks keagamaan Islam. Nikah mut'ah tidak hanya dibicarakan dalam al-Qur'an, namun juga terdapat dalam hadis Nabi Muhammad saw. Kendati demikian, diperlukan perhatian dan pemahaman yang cukup untuk menerapkan sebuah hadis dalam kehidupan sehari-hari. Ulama hadis sepakat bahwa segala yang diucapkan, dikerjakan dan ditetapkan Nabi saw. dalam bentuk sunah ataupun hadis memiliki fungsi untuk menjelaskan, menafsirkan, mengklarifikasi dan memverifikasi bahkan memvalidasi sumber ajaran utama, al-Qur'an, dalam rangka dapat dijadikan pedoman hidup bagi masyarakat muslim, baik secara individual maupun dalam kehidupan sosialnya. ${ }^{5}$ Dalam memahami hadis Nabi, sikap para ahli hadis tidaklah sama karena berbagai faktor kepentingan, kapabilitas serta kompetensi masing-masing. ${ }^{6}$

Sikap para ahli hadis dalam memahami sebuah hadis tidak secara universal, misalnya ulama fikih hanya memfokuskan pada aspek hukum, ulama kalam hanya memfokuskan pada aspek teologi dan eskatologi dan sebagainya. Sehingga hal ini akan berimplikasi pada pemahaman teks hadis yang mereka pahami.

${ }^{5}$ Muhammad Yusuf, Metode dan Aplikasi Pemaknaan Hadis: Relasi Iman dan Sosial-Humanistik Paradigma Integrasi-Interkoneksi (Yogyakarta: Teras, 2009), 2.

${ }^{6}$ Muhammad Yusuf, 2. 
Sebagian memahaminya secara tekstual dan ada pula yang kontekstual serta ada juga yang menggabungkan keduanya. Tingkat pengetahuan dan perkembangan metodologi keilmuan masyarakat yang semakin kritis dan terdidik memerlukan kerangka pemikiran yang tidak terkesan monoton dan bersifat normatif doktriner yang kurang menggunakan bahasa sosial yang mudah dipahami umat dan tanpa mengetahui implikasi sosial dari pemikiran tersebut sehingga yang terpenting adalah bagiamana menerapkan ajaran sosial humanistik yang terkandung dalam teks lama pada konteks sosial masa kini tanpa mengubah strukturnya. ${ }^{7}$

Maka artikel ini merupakan artikel yang berbasis penelitian pustaka dengan sumber utama adalah literatur-literatur tentang hadis tematik, nikah mut'ah dan sumber-sumber lainnya sebagai data penunjang dalam artikel ini. Artikel ini berupaya mengkaji tentang nikah mut'ah dengan metodologi tematik, agar hadis mengenai nikah mut'ah dapat di pahami secara universal dan tidak terkotak-kotak.

\section{Pembahasan}

\section{Metodologi Tematik Pemahaman Hadis}

Kata metode berasal dari bahasa Yunani yaitu mhetodos, yang berarti cara atau jalan. Dalam bahasa Inggris yaitu method. Adapun dalam bahasa Arab metode berarti thariqah yang artinya jalan, sistem atau keterlibatan dalam melaksanakan sesuatu. ${ }^{8}$ Dalam bahasa Indonesia kata tersebut mengandung arti cara teratur yang digunakan untuk melaksanakan suatu pekerjaan agar tercapai sesuai dengan yang dikehendaki atau cara kerja yang bersistem untuk memudahkan pelaksanaan suatu kegiatan guna mencapai tujuan

7 Muhammad Yusuf, Metode dan Alikasi Pemaknaan Hadis (Yogyakarta: Bidang Akademik UIN Sunan Kalijaga, 2008), 10.

${ }^{8}$ Nur Uhbiyati, Ilmu Pendidikan Islam (IPI) (Bandung: CV Pustaka Setia, 1999), 123. 
yang ditentukan. ${ }^{9}$ Sedangkan menurut istilah metode adalah suatu sistem atau cara yang mengatur suatu tujuan. Kata metodologi dalam Kamus Besar Bahasa Indonesia adalah ilmu tentang metode atau uraian tentang metode. ${ }^{10}$ Dengan demikian metodologi adalah cara yang tersistem agar dapat memudahkan dalam mencapai tujuan yang diinginkan.

Kata tematik dalam studi hadis yaitu maudbu'i. Tematik adalah salah satu metode dalam membahas sesuatu yang sesuai dengan tema atau judul yang telah ditetapkan atau ditentukan. kemudian tema tersebut dikaji secara mendalam dan tuntas dari berbagai aspek yang terkait dengannya. ${ }^{11}$ Pemahaman dalam bahasa Arab disebut dengan istilah fahm yaitu sinonim dengan kata syarh. Kata syarb berasal dari bahasa Arab syaraha-yasyrahu-syarban yang artinya menerangkan, membukakan, melapangkan. Istilah syarb atau pemahaman biasanya digunakan untuk hadis, sedangkan untuk al-Qur'an menggunakan kata tafsir. Secara subtansial keduanya sama, yakni sama-sama menjelaskan maksud, arti atau pesan. Tetapi secara istilah keduanya berbeda, istilah tafsir menjelaskan maksud, arti, kandungan atau pesan ayat al Qur'an. Sedangkan syarb menjelaskan maksud, arti, kandungan, atau pesan yang terkandung dalam hadis. ${ }^{12}$

Hadis adalah sumber kedua dalam Islam setelah al-Qur'an. Keduanya telah disepakati oleh ahli hukum Islam sebagai sumber primer dari hukum Islam. Peranan hadis terhadap al-Qur'an sangatlah besar, yaitu memberikan penjelasan terhadap ayat-ayat yang masih global, merinci dan memberi ketetapan baru. ${ }^{13}$ Pada

\footnotetext{
9 Tim Penyusun Kamus Pusat Bahasa KBBI, Kamus Besar Bahasa Indonesia (Jakarta: Balai Pustaka, 2005), 740.

${ }^{10}$ Tim Penyusun Kamus Pusat Bahasa KBBI, 741.

${ }^{11}$ Nashruddin Baidan, Metodologi Penafsiran Al-Qur'an (Yogyakarta: Pustaka Pelajar Offset, 1998), 151.

12 Khamdan, Mursidi, dan Dkk, Studi Hadis Teori \& Metodologi (Yogyakarta: Idea Pres Yogyakarta, 2012), 73.

${ }^{13}$ Hamin Ilyas dan Dkk, Perempuan-Perempuan Tertindas? Kajian Hadis-Hadis Misogonis (Yogyakarta: ELSAQ Press, 2005), 65.
} 
masa Rasulullah, hadis melekat dalam memori para sahabat dan belum banyak ditulis, bahkan di awal-awal wahyu, hadis dilarang untuk dicatat dikarenakan takut bercampur dengan al-Qur'an. Jadi, yang dimaksud dari metodologi tematik pemahaman hadis ialah sebuah cara yang sistematis dalam memahami hadis dengan tematema tertentu. Pada masa kini sangat relevan jika menggunakan metode ini, karena dapat memberikan keterangan kepada manusia sesuai dengan topik yang ingin diketahui.

Metode mandhu'i (tematik) adalah metode pembahasan hasil sesuai dengan tema tertentu yang dikeluarkan dari sebuah buku hadis. Semua hadis yang berkaitan dengan tema tertentu, ditelusuri dan dihimpun yang kemudian dikaji secara mendalam dan tuntas dari berbagai aspek. ${ }^{14}$ Metode tematik merupakan suatu cara memahami hadis-hadis yang berada dalam satu tema. Karena ada kalanya perawi hadis dalam meriwayatkan hadis berbeda redaksinya sesuai dengan apa yang mereka alami dan apa yang mereka lihat dari Nabi, sementara tema yang dipahami adalah sama. Oleh karena itu, untuk memahami makna hadis digunakan pendekatan tematik yaitu dengan menghimpun atau mengumpulkan beberapa hadis yang bertemakan sama untuk selanjutnya dikelompokkan sehingga dapat tertangkap makna dan maksud dari hadis tersebut.

Langkah-langkah metode maudh'i: a) Menentukan sebuah tema yang akan dibahas; b) Menghimpun hadis-hadis yang terjalin dalam tema yang telah ditentukan; c) Menyusun kerangka pembahasan (outline) dan mengklarifikasikan hadis-hadis yang telah terhimpun sesuai dengan spesifik pembahasannya; d) Mengumpulkan hadis-hadis semakna yang satu peristiwa (tempat dan waktu terjadinya sama); e) Menganalisis hadis-hadis tersebut dengan menggunakan berbagai teknik dan pendekatan; f) Meskipun metode ini tidak mengharuskan uraian tentang pengertian kosa kata, namun kesempurnaannya dapat dicapai jika pensyarah berusaha memahami kata-kata yang terkandung dalam

${ }^{14}$ Shihab Quraish, Membumikan Al-Qur'an (Bandung: Mizan, 1996), 43. 
hadis, sehingga akan lebih baik jika pensyarah menganalisis matan hadis yang mencakup pengertian kosa kata, ungkapan, asbab alwurud dan hal-hal lain yang biasa dilakukan metode tablili; g) Menarik kesimpulan makna yang utuh dari hasil analisis terhadap hadis-hadis tersebut.

Keberadaan metode mandhu'i turut membantu memecahkan permasalahan yang terdapat dalam masyarakat yang diambil dari petunjuk-petunjuk al-Qur'an dan hadis. Kelebihan utama pada metode maudhu'i adalah menjawab tantangan zaman dengan permasalahannya yang semakin kompleks dan rumit dilihat dari berbagai aspek kehidupan. Adapun kelebihan lain metode maudhu'i yakni $:^{15}$ a) Metode mandhu'i disusun secara praktis dan sistematis dalam memecahkan permasalahan yang timbul. Hal ini memungkinkan masyarakat untuk mendapatkan petunjuk alQur'an dan hadis dengan waktu yang lebih efektif dan efisien; b) Metode maudhu'i membuat tafsir al-Qur'an dan hadis selalu dinamis sesuai dengan tuntutan zaman. Sehingga, masyarakat akan merasa bahwa al-Qur'an dan hadis selalu aktual, tidak pernah ketinggalan zaman dan mereka tertarik untuk mengamalkan ajaran-ajarannya; c) Dengan ditetapkannya tema tertentu, maka pemahaman kita terhadap hadis Nabi saw. menjadi utuh. Kita hanya perlu membahas segala aspek yang berkaitan dengan tema tersebut tanpa perlu membahas hal-hal lain di luar tema yang telah ditetapkan; d) Penjelasan antar hadis dalam metode maudhu'i bersifat lebih integral dan kesimpulan yang dihasilkan mudah dipahami. ${ }^{16}$

Jadi, metode maudhu'i hanya membahas hadis-hadis dengan satu tema saja, sehingga tidak membahas hadis di luar dari tema yang telah ditetapkan. Dengan demikian, metode maudbu'i ini kurang tepat bagi seseorang yang menginginkan penjelasan secara terperinci mengenai hadis-hadis dilihat dari segala aspek.

15 Nashruddin Baidan, Metodologi Penafsiran Al-Qur'an (Yogyakarta: Pustaka Pelajar, 2005), 30.

${ }^{16}$ Abdul Majid Khon, Takhrij dan Metode Memahami Hadis (Jakarta: Amzah, 2014), 55. 


\section{Hadis-Hadis Nikah Mut'ah}

Dalam KBBI mut'ah adalah sesuatu (uang, barang dan sebagainya) yang diberikan suami kepada istri yang diceraikannya sebagai bekal hidup (penghibur hati) bekas istrinya. Kata-kata mut'ah pada dasarnya memberi kesenangan, kegembiraan dan kelapangan. Akan tetapi kata mut'ah yang dimaksud dalam artikel ini adalah terkait tentang mencari kesenangan dalam masa terbatas yang dinamakan "perkawinan kontrak", yang mana hal ini bukan dinamakan pernikahan, sebab pernikahan berarti untuk selamanya, di mana tidak akan didapatkan dari nikah mut'ah karena hanya terjadi dalam masa waktu tertentu tanpa suatu tanggung jawab yang layak dan wajar apalagi terhormat. Hal tersebut tidak memenuhi syarat kesucian niat, maksud mencari pasangan, tujuan mendapatkan anak, manfaat timbal balik, cinta yang menjadi dasar pengorbanan, menghormati manusia sebagai makhluk yang termulia yang berbudi pekerti dan jiwa yang tinggi. ${ }^{17}$

Jumbur ulama Ahl al-Sunnah hanya mengenal nikah permanen saja dan membatalkan nikah mut'ah, sementara dalam konsep Syiah selain melalui nikah permanen, hubungan seksual juga diperbolehkan melalui nikah mut'ah. Maka pencantuman rukun-rukun nikah mut'ah menurut $\mathrm{Ahl}$ al-Sunnah tidak perlu disebutkan. Jurisprudensi Syiah menetapkan empat macam rukun mut'ah, antara lain: ${ }^{18}$ a) Sighat akad nikah, yaitu adanya $\ddot{j} a b$ dan qabul dengan mempergunakan dua kata yang dapat menunjukkan atau menimbulkan pengertian yang dimaksud dan rela dengan pernikahan mut'ah dengan cara yang dimengerti kedua belah pihak; b) Calon suami dan istri; seorang muslim dianjurkan melakukan akad mut'ah hanya dengan muslimah yang suci. Di sini yang dimaksudkan dengan "suci" ('afifah) oleh para

17 Fuad Mohd Fachruddin, Kawin Mut'ah dalam Pandangan Islam (Jakarta: Pedoman Ilmu Jaya, 1992), 27.

${ }^{18}$ Muhammad Arif Slamet Raharjo, “Telaah Hadis Nikah Mut'ah (Takhrij Terhadap Hadis Kebolehan Nikah Mut'ah)" (Salatiga, Skripsi STAIN Salatiga, 2010), 40. 
penulis klasik adalah seorang yang tidak pernah melakukan zina dan mengikuti syariat dalam aktivitasnya; c) Periode waktu; periode atau jangka waktu ini harus disebutkan sesuai dengan ketentuan yang telah disepakati oleh kedua belah pihak, baik lama maupun sebentar saja dan juga harus disepakati bentuk waktunya, seperti berapa hari, bulan atau tahun secara tegas dan jelas sehingga tidak bisa lebih atau kurang dari jangka waktu yang telah ditentukan tersebut. Selain itu, dalam nikah mut'ah juga menentukan kalender mana yang akan digunakan, apakah Masehi atau Hijriyah? Batas waktu yang disepakati oleh calon suamiistri mut'ah harus diucapkan dengan jelas, jika tidak atau lupa menyebutkannya maka ijab-qabul itu akan mengikat menjadi perkawinan da'im (permanen). Lantas untuk melepas ikatan perkawinan ini diperlukan ucapan talak yang harus disaksikan oleh dua orang yang adil. Dalam mazhab Syiah, saksi pada waktu nikah hanya sunah, dan wajib pada waktu talak; d) Mahar, ketika proses ijab-qabul disebutkan mahar (mas kawin) yang telah disepakati oleh kedua belah pihak. Kadar mahar yang telah ditentukan baik dari segi bentuk mapun jumlahnya tersebut bertujuan untuk menghilangkan kesalahpahaman. Selain itu, mahar tersebut merupakan milik dari suami yang diperolehnya secara halal baik sedikit atau pun banyak, bahkan meskipun berupa segenggam makanan. Wanita boleh meminta seluruh mahar pada awal pernikahan. Dalam kasus ini pria tidak boleh mengambil kembali mahar itu, apapun keadaannya.

Terdapat sejumlah hadis yang membicarakan tentang persoalan nikah mut'ah. Namun, sebelum memahami hadis-hadis tersebut penulis terlebih dahulu menghimpun semua hadis tersebut dengan melakukan takhrij hadis. Metode takhrij hadis yang penulis gunakan adalah metode takhrij al-hadits bi al-laf z̧ $h$ yaitu menelusuri hadis-hadis yang bersangkutan di berbagai kitab hadis primer dengan mengandalkan kata kunci tertentu seperti kata mut'ah dan sebagainya. Dalam melakukan takbrij, penulis menggunakan software Maktabah Syamilah untuk mempermudah dan mempercepat 
langkah pencarian hadis. Setelah diperoleh informasi mengenai posisi di mana hadis-hadis yang sedang diteliti berada dalam kitabkitab hadis primer, penulis merujuk dan mengutip langsung dari kitab aslinya.

Berdasarkan hasil takbrij hadis dengan menggunakan kata kunci mut'ah penulis menemukan bahwa hadis-hadis yang memuat kata mut'ah terdapat pada kitab Sahih al-Bukhari sebanyak 16 kali, Sahih Muslim sebanyak 31 kali, Sunan al-Turmudzi sebanyak empat kali, Sunan al-Nasa'i sebanyak 15 kali, Sunan Abu Dawud sebanyak empat kali, Sunan Ibn Majah sebanyak enam kali, Musnad Ahmad bin Hanbal sebanyak 35 kali, Muwaththa' Malik sebanyak tujuh kali, dan Sunan al-Darimi sebanyak enam kali. Namun dari semua kata mut'ah, tidak semuanya bermakna nikah mut'ah. Sementara hadis-hadis yang membicarakan tentang nikah mut'ah yaitu berbeda antara satu dengan lainnya. Ada hadis-hadis yang membolehkan dan ada pula hadis-hadis yang melarang.

Hadis-hadis yang membolehkan nikah mut'ah di antaranya:

a. Riwayat Muslim dari Abdullah ${ }^{19}$
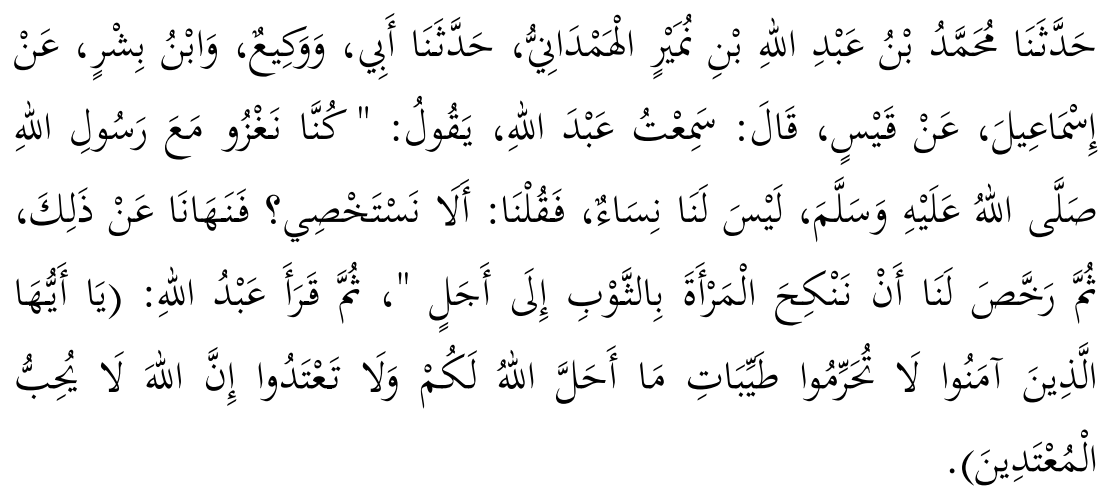

19 Muslim, Sabih Muslim, vol. 2 (Beirut: Dar al-Kutub al-'Ilmiyyah, 1991), 1022. Hadis serupa juga terdapat pada Muhammad bin Isma'il al-Bukhari, $A l$ Jami' al-Shabih al-Musnad min Hadits Rasulillah saw. wa Sunanih wa Ayyamih, vol. 3 (Kairo: al-Maktabah al-Salafiyah, 1980), 356-57. Ahmad ibn Hanbal, Musnad Ahmad, vol. 7 (Beirut: Muassasah al-Risalah, 2001), 93. 
Telah menceritakan kepada kami Mubammad bin Abdullah bin Numair al-Hamdani, telab menceritakan kepada kami bapakku dan Waki' dan Ibnu Bisyr dari Isma'il dari Qais, ia berkata, saya mendengar Abdullah berkata: Kami pernah berperang bersama Rasulullah saw. tanpa membawa isteri, lalu kami berkata, "Apakah sebaiknya kita mengebiri kemaluan kita?" Rasulullah saw. melarang kami berbuat demikian, dan beliau memberikan keringanan pada kami untuk menikahi perempuan sampai pada batas waktu tertentu dengan mas kawin pakaian. Kemudian Abdullah bin Mas'ud membaca ayat: "Hai orang-orang yang beriman, janganlab kamu haramkan apa-apa yang baik yang telah Allab halalkan bagi kamu, dan janganlah kamu melampaui batas. Sesunggubnya Allah tidak menyukai orang-orang yang melampaui batas."

b. Riwayat Muslim dari Jabir bin Abdullah dan Salamah bin alAkwa $^{, 20}$
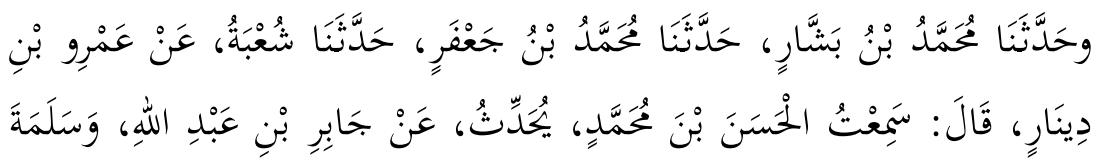

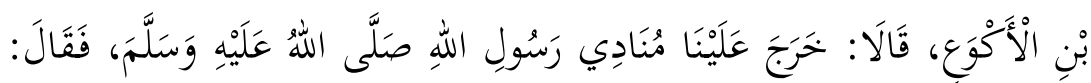

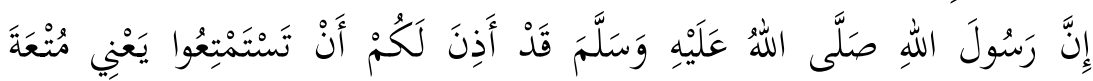
النّبَاِِي.

Dan telab menceritakan kepada kami Mubammad bin Basyar, telah menceritakan kepada kami Muhammad bin Ja'far, telah menceritakan kepada kami Syu'bah dari Amr bin Dinar, ia berkata, saya mendengar al-Hasan bin Mubammad menceritakan dari Jabir bin Abdullab dan Salamah bin al-Akwa', ia berkata: utusan Rasulullah saw. datang kepada kami, lalu dia berkata, "Rasulullah saw. telah mengizinkan kalian untuk nikah mut'ah."

${ }^{20}$ Sabih Muslim, 2:1022.

TAJDID vol. 19, No. 2, Juli - Desember 2020 | 255 
Hadis-hadis yang melarang nikah mut'ah di antaranya:

a. Riwayat Bukhari dari 'Ali bin Abi Thalib'

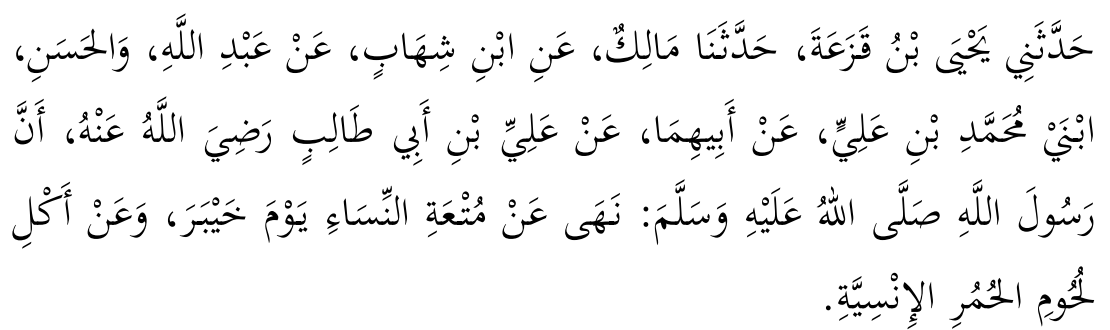

Telah menceritakan kepadaku Yabya bin Qaza'ah, telah menceritakan kepada kami Malik dari Ibnu Syihab dari Abdullah dan al-Hasan, dua anak. Mubammad bin 'Ali dari Bapak keduanya dari 'Ali bin Abu Thalib ra. babwa Rasulullah saw. melarang nikah mut'ah (perkawinan dengan waktu terbatas semata untuk bersenangsenang) dan melarang makan daging keledai jinak pada perang Khaibar.

b. Riwayat Abu Dawud dari Sabrah ${ }^{22}$

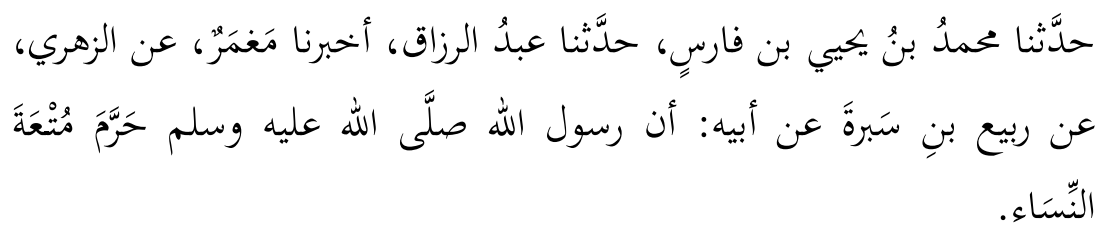

Telah menceritakan kepada kami Mubammad bin Yahya bin Faris, telah menceritakan kepada kami Abdurrazzaq, telah mengabarkan kepada kami Ma'mar dari al-Zubri dari Rabi' bin Sabrah dari ayahnya bahwa Nabi saw. telah mengharamkan menikahi wanita secara mut'ah.

Penulis tidak menuliskan semua riwayat mengenai nikah mut'ah karena pada dasarnya secara garis besar hadis-hadis

21 al-Bukhari, Al-Jami' al-Shabih al-Musnad min Hadits Rasulillah saw. wa Sunanih wa Ayyamih, 3:138-39. Hadis serupa terdapat pula pada Ibn Majah, Sunan Ibn Majah, vol. 1 (Kairo: Dar Ihya' al-Kutub al-'Arabiyah, t.t.), 630-31. Abdullah al-Darimi, Sunan al-Darimi, vol. 2 (Karachi: Qadimi Kutub Khanah, t.t.), 118.

22 Abu Dawud al-Sijistani, Sunan Abi Dawnd, vol. 2 (Beirut: Dar Ibn Hazm, 1997), 386. 
tersebut diriwayatkan dengan narasi yang sama antara satu dengan lainnya. Oleh karena itu, penulis hanya menulis sebagian riwayat sebagaimana di atas. Selanjutnya, berikut diuraikan beberapa kitab yang membicarakan tentang nikah mut'ah. Dalam kitab Bidayah alMujtahid juz 2 hal 58 yang di riwayatkan oleh al-Zaila'i dalam bukunya Tibyan al-Haqaiq Syarh Kanz al-Daqaiq, hadis yang diriwayatkan oleh Atha' beliau berkata: "Aku pernah mendengar perkataan Jabir ibn Abdullah yang isinya: "Kita melakukan mut'ah di zaman Nabi saw. dan di zaman Abu Bakar sampai permulaan kepemimpinan Umar, kemudian Umar melarang orang-orang untuk. melakukan nikah mut'ah tersebut." Al-Zaila'i menambahkan bahwa Abu Said al-Khudri berkata: inilah pendapat yang diikuti oleh orangorang syiah. ${ }^{23}$

Dalam Musnad Ahmad juz 3 hal 336 dan 363; al-Ghadir juz 6 hal 210 yang dikutip dari Kanz al-Ummal juz 8 hal 293 yang diriwayatkan oleh Thabari dan Suyuthi. Abi Nadrah meriwayatkan hadis dari Jabir ibn Abdullah ia berkata: "Kita melakukan dua jenis mut'ah di zaman Nabi saw., yang pertama adalab haji tamattu' dan yang kedua adalah nikah mut'ah. Kemudian Umar melarangnya dan kita tidak. lagi melakukannya." Sanadnya sahih dan diriwayatkan oleh Ashim juga. ${ }^{24}$ Shahih muslim juz 4 hal 38; Ahkam al-Qur'an karangan Jashshash juz 2 hal 174; al-Durr al-Mantsur juz 2 hal 216, Abi Nadhrah berkata: Ibnu Abbas membolehkan nikah mut'ah, tetapi Ibnu al-Zubair melarangnya. Kemudian aku ceriatakn pertentangan tersebut kepada Jabir bin Abdillah kemudian Jabir menjawab: peristiwa tersebut terjadi pada diri saya. Kita memang melakukan nikah mut'ah pada zaman Rasul saw.” Tetapi saat Umar menjadi khalifah beliau berkata; Allah telah menghalalkan nikah tersebut terhadap Rasul-Nya dan dikerjakan di mana-mana. Sempurnakan ibadah haji dan umrah kalian sebagaimana yang diperintahkan dan jauhilah mengawini wanita dengan cara berjangka ini dan apabila

${ }^{23}$ Jafar Murtadha Al-Amili, Nikah Mut'ah dalam Islam Kajian Ilmiah Berbagai Mazhab (Jakarta: CV Firdaus, 1992), 60.

${ }_{24}$ Al-Amili, 61. 
masih aku dapati orang yang melakukan nikah semacam ini aku akan rajam dia dengan batu. Sanad ini sahih. ${ }^{25}$

Ada versi lain dari hadis yang sama-sama diriwayatkan dari Abi Nadhrah dalam Sunan Baihaqi juz 7 hal 206 dengan tambahan. Muslim juga meriwayatkan dari seorang bernama Hammam dalam Musnad Ahmad juz 1 hal 52 yang isinya Abi Nadhrah menceritakan kepada Jabir tentang larangan nikah mut'ah dari Ibnu Zubair, padahal Ibnu Abbas membolehkannya. Dijawab oleh beliau: "Pada diriku berlaku hadis yang disabdakan di zaman Nabi saw. dan di zaman Abu Bakar." Tetapi pada saat Umar menjadi khalifah, beliau berdiri di hadapan khalayak ramai sambil menyampaikan khutbah yang isinya: 'Al-Qur'an adalah al-Qur'an, Rasul adalab Rasul dan dua jenis mut'ah yang terdapat di zaman beliau itu aku mengharamkannya sekarang; saya melarang kedua jenis mut'ah tersebut. Yang pertama nikah mut'ah dan aku tidak melihat seseorang melakukan nikah itu kecuali aku rajam dia dengan batu dan yang kedua adalab haji tamattu." Sanad hadis tersebut sahih dari riwayat Ahmad Bin Hanbal. $^{26}$

Apabila membedah persoalan mut'ah dengan menggunakan perangkat metodologi yang dikemukakan oleh Fazlur Rahman, maka akan berkaitan dengan teori atau metode sebuah gerakan ganda (a double movement). Pada langkah pertama penafsiran berdasarkan metode sebuah gerakan ganda yang dioperasikan pada kasus nikah mut'ah dinyatakan bahwa mut'ah diperbolehkan oleh Nabi saw. Hal itu terjadi pada kasus peperangan sebagai dampak dari adanya sebagian sahabat yang tidak dapat menahan hasrat biologisnya dan menanyakan kepada Nabi saw. Berkenaan dengan konteks adat istiadat atau lembaga Arab pra-Islam, terdapat beberapa praktik nikah atau perkawinan seperti poligami, poliandri, mut'ah, al-sabyu (perkawinan antara laki-laki yang menang perang dengan perempuan dari suku yang

\footnotetext{
${ }^{25}$ Al-Amili, 63.

26 Al-Amili, 64.
} 
kalah), perkawinan dengan budak, al-maqtu (perkawinan antara anak laki-laki dengan ibu tirinya setelah bapaknya meninggal), alistibda' (seorang laki-laki menyuruh istrinya untuk disetubuhi oleh laki-laki yang dipilih olehnya), al-syighar (perkawinan silang antara dua orang laki-laki yang sama-sama mempunyai perempuan di bawah perwaliannya, dan mengawini dua orang perempuan bersaudara. Langkah kedua dari teori a double movement, dapat dinyatakan bahwa mut'ah dilaksanakan ketika seorang lelaki tidak dapat menahan hasrat biologisnya karena jauh dari istri dan dilakukan untuk menjaga kemaluannya (agar tidak berzina ataupun melakukan onani, masturbasi, ataupun kebiri).

Pendapat umum dari empat mazhab hukum Sunni sehubungan dengan alasan mut'ah diperbolehkan dan kemudian dilarang adalah pada awal Islam, umat Muslim adalah minoritas dan sering berperang. Banyak di antara mereka tidak dapat menikah dan membangun keluarga, karena mereka senantiasa dipanggil untuk melakukan perjalanan jauh dan berperang dengan kaum kafir. Lebih jauh, mereka baru saja masuk Islam, dan sebelumnya mereka terbiasa dengan kebiasaan seksual Arab pra Islam, yang mempunyai harem dengan istri yang banyak. Mereka akan berhubungan seksual dengan istri mana saja yang mereka kehendaki, dan meninggalkan istri yang sudah tidak menarik hatinya lagi. Satu-satunya prinsip dalam kehidupan seksual mereka adalah nafsu dan keinginan. Ketika orang ini menjadi muslim, dengan ajaran yang ketat soal seksual, akan sulit bagi dirinya untuk berperang dengan tanpa kesempatan untuk memuaskan hasrat seksual mereka. Karenanya wajar bahwa mereka diperbolehkan untuk melakukan pernikahan sementara, khususnya karena pernikahan ini tidak menyertakan ikatan permanen yang membutuhkan perhatian dan perawatan penuh terhadap istri dan anak. Juga, pada saat berperang cara-cara biasa untuk meredakan dorongan seksual seperti puasa tidak dapat diapakai karena tentunya juga akan mengurangi kemampuan berperang para tentara tersebut. 
Oleh karena itu, kita lihat bahwa alasan mut'ah diperbolehkan sebab situasi khusus di era awal Islam. Sehingga menurut empat mazhab yang umum dikenal sepakat hukuman untuk orang yang melakukan pernikahan sementara tidak sama dengan hukuman untuk pezina. Dalam kasus pezina hukumannya adalah seratus kali cambukan untuk masing-masing pihak dalam kasus wanita yang belum menikah dan dirajam sampai mati dalam kasus wanita yang sudah menikah. Hukuman untuk nikah mut'ah didefenisikan sebagai ta'zir, yakni lebih rendah dari hukuman zina, tergantung kepada keadaan opini hakim.

Adapun beberapa ayat al-Qur'an yang menyinggung tema pernikahan mut'ah. Ayat-ayat tersebut adalah sebagai berikut:

a. QS. Al-Azhab [33]: 28

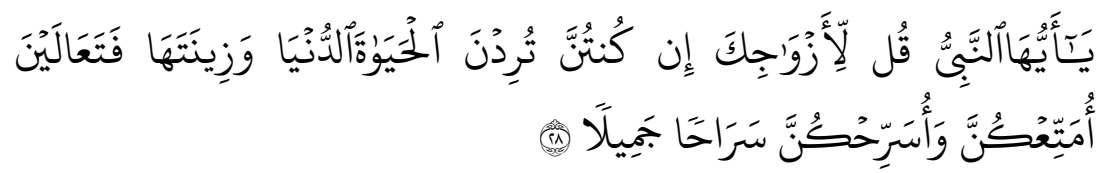

Hai Nabi, katakanlah kepada istri-istrimu: "Jika kamu sekalian mengingini kehidupan dunia dan perbiasannya, maka marilah supaya kuberikan kepadamu mut'ah dan aku ceraikan kamu dengan cara yang baik. "27

b. QS. Al-Baqarah [2]: 236

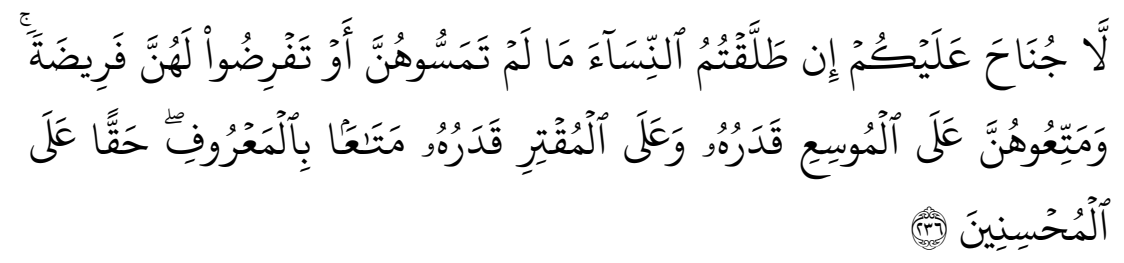

Tidak ada kewwajiban membayar (mahar) atas kamu, jika kamu menceraikan isteri-isteri kamu sebelum kamu bercampur dengan mereka dan sebelum kamu menentukan maharnya. Dan hendaklah kamu berikan suatu mut'ah (pemberian) kepada mereka. Orangyang

${ }^{27}$ Departemen Agama RI, Al-Qur'an Al-Karim dan Terjemahannya (Jakarta: Maghfiroh Pustaka, 2006), 421. 
mampu menurut kemampuannya dan orang yang miskin menurut kemampuannya (pula), yaitu pemberian menurut yang patut. Yang demikian itu merupakan ketentuan bagi orang-orang yang berbuat kebajikan. ${ }^{28}$

c. QS. Al-Nisa' [4]: 24

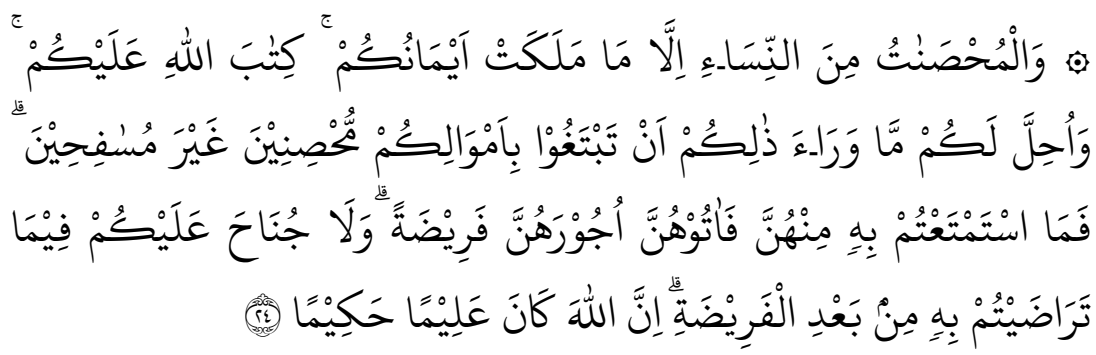

Dan (diharamkan juga kamu mengawini) wanita yang bersuami, kecuali budak-budak yang kamu miliki (Allah telah menetapkan bukum itu) sebagai ketetapan-Nya atas kamu. Dan dibalalkan bagi kamu selain yang demikian (yaitu) mencari isteri-isteri dengan bartamu untuk dikawini bukan untuk beræina. Maka isteri-isteri yang telah kamu nikmati (campuri) di antara mereka, berikanlah kepada mereka maharnya (dengan sempurna), sebagai suatu kewajiban; dan tiadalah mengapa bagi kamu terhadap sesuatu yang kamu telah saling merelakannya, sesudah menentukan mahar itu. Sesunggubnya Allab Maha Mengetabui lagi Maha Bijaksana. ${ }^{29}$

Berdasarkan dari ketiga ayat tersebut dapat disimpulkan bahwa maksud dari mut'ah adalah pemberian berupa uang atau benda lainnya yang diberikan kepada mantan istri setelah ia mengorbankan segala sesuatu. Islam mengajarkan bahwa untuk para suami yang telah mendapatkan kebahagiaan itu agar dapat memberikan sedikit kesenangan dan kelapangan bagi mantan istrinya sampai ia mendapatkan jalan hidup baru. Jangan

${ }^{28}$ Departemen Agama RI, 38.

${ }^{29}$ Departemen Agama RI, 82.

TAJDID vol. 19, No. 2, Juli - Desember 2020 | 261 
memandang wanita ibarat pakaian bila sudah berbau dibuang tanpa rasa segan dan malu atau merasa pilu. ${ }^{30}$

\section{Melakukan Pengembangan dan Pengembaraan Makna dengan Pendekatan Kontekstual}

Pemahaman hadis memerlukan metodologi serta pemahaman yang tepat agar dalam penelitian terhadap hadis benarbenar menemukan atau mengungkapkan makna (pesan) sebenarnya dari kandungan hadis dengan tujuan agar tidak terperosok kepada kesalahan yang disebabkan ketidak tahuan penyebab dan faktor yang mempengaruhi hadis itu muncul (asbab al-wurud), dan situasi saat hadis itu muncul.

Pendekatan yang digunakan agar memperoleh pemahaman secara benar dan komprehensif yaitu: a) Pendekatan sosio historis, ulama sepakat bahwa nikah mut'ah pernah dibolehkan dan menjadi salah satu bentuk pernikahan pada periode awal pembinaan hukum Islam. Mereka berpendapat bahwa nikah mut'ah diperbolehkan karena pada saat itu umat Islam jumlahnya sedikit dan keadaan ekonominya terbatas, sedangkan tenaga mereka dikonsentrasikan untuk menghadapi perluasan Islam serta penyesuaian dengan agama Isam. Kondisi seperti ini tidak memungkinkan mereka dapat hidup berkeluarga layaknya suami istri dan membina anakanak mereka sebagaimana dikehendaki dari sebuah pernikahan; b) Pendekatan antropologis, manusia merupakan makhluk bebas, kreatif, dinamis dan berhak menentukan dan merencanakan dunia dan aturan-aturan sosial sendiri, artinya manusia mempunyai kebebasan hak untuk menentukkan dunia dan aturan sosialnya sendiri (termasuk kehidupan seksualnya). Pengaturan tentang seksualitas manusia secara sosiologis seperti pelarangan atau tidak diakuinya nikah mut'ah di Indonesia dan pemberian ijin nikah mut'ah di Iran merupakan perwujudan bahwa seksualitas sebenarnya merupakan produk masyarakat atau sebagai bentukan

${ }^{30}$ Fachruddin, Kawin Mut'ah dalam Pandangan Islam. 
sosial budaya, bukan merupakan produk naluri insting manusia. Hal ini terjadi melalui mekanisme mengenai seksualitas yang dapat dikendalikan dan diarahkan perubahannya sesuai dengan kepentingan masyarakat. ${ }^{31}$ Jadi, fenomena nikah mutah merupakan bentukan sosial budaya, konstruksi sosial, sehingga nikah mut'ah dapat dimaknai suatu bentuk uapaya melegalkan bentuk perzinaan, perselingkuhan, upaya melepaskan diri dari tekanan kemiskinan, upaya melegitimasi hasrat seks supaya tidak dikatakan zina. Sehinnga secara keseluruhan sangat tergantung pada masyarakatnya; c) Pendekatan hukum dan psikologis, status nikah mut'ah yang tidak jelas, karena dalam hukum tidak dilengkapi surat resmi dari kantor KUA, nikah mut'ah juga tidak diakui dalam UU No. 1 tahun 1974. Dampak yang ditimbulkan tidak hanya mengancam status pernikahan, namun bila sudah melahirkan anak, akan mempengaruhi beberapa aspek, baik dari hukum terhadap anak yang dilahirkan dan juga psikologis anak. Lalu timbul masalah siapa yang akan bertanggung jawa untuk membesarkan anak dan menafkahinya. Nikah mut'ah yang umum terjadi adalah pernikahan dibawah tangan, sehingga hal ini membuat pernikahan tersebut tidak menjadi sah secara agama ataupun hukum Negara. Berdasarkan undang-undang pernikahan, status anak yang lahir dalam pernikahan di bawah tangan hanya memiliki hubungan perdata dengan ibunya, sedangkan hubungan keperdataan dengan ayahnya terputus, karena pernikahan tersebut tidak diakui secara hukum Negara. Maka hak waris yang seharusnya diterima si anak akan terputus dari sang ayah, hal tersebut karena disamakan dengan kelahiran anak di luar pernikahan. Selain berdampak kepada hukum, pernikahan ini tentu berdampak kepada psikologis anak dan perempuan yang menjadi korban. Secara psikologis dampak nikah mut'ah ini adalah membunuh karakter dan hidup korban. $^{32}$

${ }^{31}$ Bagus Haryono, "Kawin Kontrak di Indonesia Fungsional Bagi Siapa," Jurnal Sosiologi DILEMA 26 (2011): 5.

${ }^{32}$ Haryono, 9. 
Maka apabila nikah mut'ah ini diterapkan akan ada beberapa implikasi dalam kehidupan sosial yaitu sebagai berikut: ${ }^{33}$ a) yakni menyalahi idealisme pernikahan, sejatinya pernikahan adalah suatu ikatan antara suami istri yang diikat oleh syariat sehingga pernikahan tersebut kuat dan langgeng kemudian dapat menghasilkan anak, namun dalam nikah mut'ah hal tersebut tidak akan tercapai, karena nikah mut'ah jauh dari kata langgeng. kebahagiaan yang dicapai dalam pernikahan ini adalah kebahagiaan semu yang hanya dominan kearah pemuasan seksual; b) Kerusakan kehidupan social, nikah mut'ah memudahkan oknum untuk menjalani kehidupan yang tidak terikat dengan ikatan apapun sehingga ia akan terlepas dari tanggung jawab perkawinan karena sejatinya syariat tidak akan membawa kerusakan dan kehancuran; c) Martabat kaum wanita, jika nikah mut'ah masih umum diterapkan maka akan banyak wanita yang terbawa dalam jurang kenistaan, kerusakan, dan banyak yang diantara mereka yang menjadi korban. Dalam pernikahan yang umum terjadi berbeda dengan nikah mut'ah yang mana dalam nikah pada umumnya harus ada perceraian yang sah secara hukum agama ataupun hukum Negara. Berdasarkan konsesus ulama tidak ada perceraian dalam nikah mut'ah. ${ }^{34}$ Ketika waktu habis, maka pernikahan itupun selesai. Ataupun jika ingin melanjutkan pernikahan maka kedua belah pihak harus memperpanjang jangka waktu dengan mengulangi akad baru. ${ }^{35}$ Menurut pandangan yang paling banyak dianut tidak ada warisan antara suami istri dalam nikah mut'ah kecuali disebutkan secara khusus sebagai syarat dari akad, jika syarat tidak disebutan maka warisan tida ada. Jadi tentunya berbeda sekali antara kedudukan wanita dalam pernikahan pada umumnya dengan pernikahan mut'ah, yakni sangat menjunjung tinggi martabat wanita. Masa depan generasi islam terkait kelahiran dan kehamilan merupakan persoalan pilihan oleh kedua belah pihak di

33 Al-Amili, Nikah Mut'ah dalam Islam Kajian Ilmiah Berbagai Maz̧hab, 64.

${ }^{34}$ Sachiko Murata, Lebib Jelas Tentang Nikah Mut'ah Pendekatan Sunni dan Syiah (Jakarta: PT. Raja Grafindo, 2001), 25.

35 Al-Amili, Nikah Mut'ah dalam Islam Kajian Ilmiah Berbagai Maz̧ab, 65. 
dalam nikah mut'ah. Sehingga ini bertentangan dengan tujuan pernikahan dalam islam yaitu untuk melanjutkan keturunan.

Berdasarkan daripada itu, kelemahan dasar-dasar argumentasi yang dikemukakan Syiah Imamiyah yang menyatakan kebolehan nikah mut'ah. Sebab mereka tidak memahami QS. Al-Nisa' [4]: 24 secara kontesktual sehingga terjadi salah interpretasi. Misalnya term "istimta" pada ayat tersebut diartikan menikmati hubungan seks dan "ajr" diartikan upah/bayaran atas pelayanan seks yang sebenarnya tidak demikian. Sebab ayat sebelumnya (QS. Al- Nisa' [4]: 23) dan ayat sesudahnya (QS. Al-Nisa' [4]: 25) menjadi indikator bahwa yang dimaksud dengan istimta' adalah hubungan melalui pernikahan. Sedangkan lafal ajr dalam konteks pernikahan lebih banyak bermakna mahar, bukan upah. Lalu dijumpainya beberapa hadis yang memberi kesan bolehnya nikah mut'ah itu terjadi pada masa permulaan Islam dan juga terjadi saat keadaan darurat (peperangan, misalnya), inilah yang disebut tadrij al-syari'ah alislamiyyah, tahapan-tahapan pelaksanaan hukum Islam. Setelah keadaan masyarakat Islam dan stabilitas negara dalam keadaan aman/terkendali maka legalitas nikah mut'ah dicabut langsung oleh Nabi saw. untuk selamanya. Hal ini sekaligus menepis anggapan bahwa larangan nikah mut'ah "hanyalah" datang dari seorang 'Umar ibn al-Khattab, melainkan langsung mendapat perhatian dan respons dari Rasulullah saw. mengingat kasus yang terjadi sungguh bukan kasus main-main. Eksistensi nikah mut'ah yang muaranya hanya untuk memenuhi kebutuhan biologis selain bertentangan dengan fungsi pernikahan juga berlawanan dengan tujuan pernikahan menurut tuntunan al-Qur'an dan sunnah Nabi saw., yaitu untuk membentuk keluarga sakinah yang dibingkai oleh nuansa mawaddah (cinta) dan rahmab (kasih sayang) antara suami dan istri dan untuk mendapatkan keturunan yang sah (reproduksi) yang diharapkan menjadi anak yang saleh, kelak menjadi generasi harapan bangsa dan penerus cita-cita perjuangan orang tuanya. Secara naluri kemanusiaan, pernikahan 
juga sekaligus merupakan sarana rekreasi yang sah dan legal bagi pemenuhan kebutuhan biologis secara terhormat. ${ }^{36}$

\section{Penutup}

Dari uraian tentang memahami nikah mut'ah dengan metodologi tematik, maka dapat disimpulkan sebagai berikut; a) Pengertian nikah mut'ah adalah pernikahan hanya untuk mencari kesenangan sesaat dalam masa yang terbatas sehingga dinamakan pernikahan kontrak dan hadis yang membicaran tentang nikah mut'ah menjelaskan bahwa awalnya pernikahan mut'ah memang dibolehkan karena mengingat situasi dan kondisi, namun kemudian dilarang; b) Pernikahan nikah mut'ah pada zaman sekarang masih saja terjadi walaupun teknologi sudah canggih, salah satu golongan yang masih melakukan adalah golongan Syiah dan yang sempat viral tidak lama ini adalah situs online yang menjalankan tentang nikah kontrak, sehingga hal tersebut mencuat sampai Mentri Yohana memberikan tanggapan bahwa itu adalah hal yang melangggar Undang-Undang dan jika masih dijalankan dan menjadi biasa akan berimplikasi terhadap kehidupan sosial, seperti tidak tercapainya keluarga yang ideal dalam sebuah pernikahan, penururnan martabat wanita karena hanya dibatasi dengan waktu serta tidak ada waris yang terikat padanya; c) Kajian tematik dalam studi hadis disebut juga dengan metode maudhu'i yakni metode pembahasan hasil sesuai dengan tema tertentu yang dikeluarkan dari sebuah buku hadis. Semua hadis yang berkaitan dengan tema tertentu, ditelusuri dan dihimpun yang kemudian dikaji secara mendalam dan tuntas dari berbagai aspek. Pembahasan hadis tematik ini lebih integral dan mudah dipahami jika ingin mengetahui suatu hadis dari satu tema saja, akan tetapi jika ingin memehami hadis secara keseluruhan maka akan sulit jika menggunakan metode ini. Kesimpulan dari metodologi tematik dalam memahami hadis nikah mut'ah adalah nikah mut'ah yang

36 A. Dzarrin al-Hamidy, "Nikah Mut'ah dalam Sorotan Hukum Islam dan Hukum Positif," Al-Qanun 11 (2008): 299-230. 
pernah diperbolehkan oleh Rasulullah, yakni pada masa awal Islam, yaitu diperkenankannya pada awal Islam ketika dalam keadaan bepergian dan peperangan. Beliau memberi kelonggaran kepada sahabat-sahabatnya yang ikut berperang di jalan Allah untuk nikah dengan batas waktu tertentu, karena dikhawatirkan mereka akan jatuh ke dalam perzinaan, sebab telah berpisah sekian lama dengan keluarganya. Kemudian nikah mut'ah itu diharamkan berdasarkan hadis-hadis, di antaranya ada yang menjelaskan haramnya nikah mut'ah hingga hari kiamat.

\section{Daftar Pustaka}

Al-Amili, Jafar Murtadha. Nikah Mut'ah dalam Islam Kajian Ilmiah Berbagai Mað̧ab. Jakarta: CV Firdaus, 1992.

As-Subki, Ali Yusuf. Figh Keluarga: Pedoman Bekeluarga dalam Islam. Jakarta: Amzah, 2010.

Baidan, Nashruddin. Metodologi Penafsiran Al-Qur'an. Yogyakarta: Pustaka Pelajar Offset, 1998.

- Metodologi Penafsiran Al-Qur'an. Yogyakarta: Pustaka Pelajar, 2005.

Bukhari, Muhammad bin Isma'il al-. Al-Jami' al-Shabih al-Musnad min Hadits Rasulillah saw. wa Sunanih wa Ayyamih. Vol. 3. Kairo: al-Maktabah al-Salafiyah, 1980.

Darimi, Abdullah al-. Sunan al-Darimi. Vol. 2. Karachi: Qadimi Kutub Khanah, t.t.

Departemen Agama RI. Al-Qur'an Al-Karim dan Terjemahannya. Jakarta: Maghfiroh Pustaka, 2006.

- Al-Qur'an Al-Karim dan Terjemahannya. Jakarta: Maghfiroh Pustaka, 2006.

Fachruddin, Fuad Mohd. Kawin Mut'ah dalam Pandangan Islam. Jakarta: Pedoman Ilmu Jaya, 1992.

Hamidy, A. Dzarrin al-. "Nikah Mut'ah dalam Sorotan Hukum Islam dan Hukum Positif." Al-Qanun 11 (2008): 219-31. 
Sinta Rahmatil Fadhilah, Umu Nisa Ristiana, dan Siti Aminah

Hanbal, Ahmad ibn. Musnad Abmad. Vol. 7. Beirut: Muassasah alRisalah, 2001.

Haryono, Bagus. "Kawin Kontrak di Indonesia Fungsional Bagi Siapa.” Jurnal Sosiologi DILEMA 26 (2011): 1-14.

Ilyas, Hamin, dan Dkk. Perempuan-Perempuan Tertindas? Kajian Hadis-Hadis Misogonis. Yogyakarta: ELSAQ Press, 2005.

Khamdan, Mursidi, dan Dkk. Studi Hadis Teori \& Metodologi. Yogyakarta: Idea Pres Yogyakarta, 2012.

Khon, Abdul Majid. Takhrij dan Metode Memahami Hadis. Jakarta: Amzah, 2014.

Majah, Ibn. Sunan Ibn Majah. Vol. 1. Kairo: Dar Ihya' al-Kutub al'Arabiyah, t.t.

Muhammad Yusuf. Metode dan Alikasi Pemaknaan Hadis. Yogyakarta: Bidang Akademik UIN Sunan Kalijaga, 2008.

- Metode dan Aplikasi Pemaknaan Hadis: Relasi Iman dan SosialHumanistik Paradigma Integrasi-Interkoneksi. Yogyakarta: Teras, 2009.

Murata, Sachiko. Lebih Jelas Tentang Nikah Mut'ah Pendekatan Sunni dan Syiah. Jakarta: PT. Raja Grafindo, 2001.

Muslim. Sabih Muslim. Vol. 2. Beirut: Dar al-Kutub al-'Ilmiyyah, 1991.

Quraish, Shihab. Membumikan Al-Qur'an. Bandung: Mizan, 1996.

Raharjo, Muhammad Arif Slamet. "Telaah Hadis Nikah Mut'ah (Takhrij Terhadap Hadis Kebolehan Nikah Mut'ah)." STAIN Salatiga, 2010.

Sachiko Murata. Lebih Jelas Tentang Nikah Mut'ah Pendekatan Sunni dan Syiah. Jakarta: PT. Raja Grafindo, 2001.

Shalih, Syaikh Fuad. Untukmu yang Akan Menikah dan Telah Menikah. Jakarta: Pustaka al-Kautsar, 2006.

Sijistani, Abu Dawud al-. Sunan Abi Dawnd. Vol. 2. Beirut: Dar Ibn Hazm, 1997.

Tim Penyusun Kamus Pusat Bahasa KBBI. Kamus Besar Bahasa Indonesia. Jakarta: Balai Pustaka, 2005. 
Interpretasi Hadis-Hadis Tentang Nikah Mut'ah

Uhbiyati, Nur. Ilmu Pendidikan Islam (IPI). Bandung: CV Pustaka Setia, 1999.

TAJDID vol. 19, No. 2, Juli - Desember 2020 | 269 